\title{
Banka Müşterilerinin E-Şikâyetlerini Şikâyet Forum Sitesi Üzerinden Analiz Etme* (Analyzing Bank Customers' E-Complaints Over the Complaint Forum Site)
}

\section{Ceylan BOZPOLAT iD a Funda ÇOPUR (iD) b}

a Nevşehir Hacı Bektaş Veli Üniversitesi, İ̈BF, Finans ve Bankacılık Bölümü, Nevşehir, Türkiye.cakdogan@nevsehir.edu.tr

b Nevşehir Hacı Bektaş Veli Üniversitesi, Sosyal Bilimler Enstitüsü, Nevşehir, Türkiye. fundacopur53@gmail.com

\begin{tabular}{|c|c|}
\hline MAKALE BİLGİSİ & ÖZET \\
\hline $\begin{array}{l}\text { Anahtar Kelimeler: } \\
\text { E-Şikâyet } \\
\text { Bankacılık Sektörü }\end{array}$ & $\begin{array}{l}\text { Amaç - Bu çalışma sikayetvar.com forum sitesinde yer alan biri kamu diğeri özel sermayeli banka } \\
\text { olmak üzere iki bankaya ait e-müşteri şikâyetlerini ve banka geribildirimlerini analiz ederek bankalara } \\
\text { e-müşteri ilişkileri yönetimi bağlamında öneriler sunmayı amaçlamaktadır. }\end{array}$ \\
\hline $\begin{array}{l}\text { E-CRM (Çevrimiçi Müşteri } \\
\text { İlişkileri Yönetimi) } \\
\text { E-WOM (Çevrimiçi Ağızdan } \\
\text { Ağıza Pazarlama) }\end{array}$ & $\begin{array}{l}\text { Yöntem - Birbirine benzer nitelikteki } 18.018 \text { metinsel şikâyeti kategorileştirmek ve nitel olarak analiz } \\
\text { etmek için içerik analizi yapılmıstır. Temmuz-Aralı } 2019 \text { olmak üzere altı aylık dönemde kamu } \\
\text { bankasına ait 7.652, özel sermayeli bankaya ait } 10.366 \text { şikâyet ayrıntılı olarak incelenmiş ve finansal } \\
\text { hizmet sağlayıcılarına daha anlaşlır bilgiler sunmak için kategorileştirilmiştir. }\end{array}$ \\
\hline $\begin{array}{l}\text { Gönderilme Tarihi } 9 \text { Şubat } 2021 \\
\text { Revizyon Tarihi } 28 \text { Ağustos } \\
2021 \\
\text { Kabul Tarihi } 10 \text { Eylül } 2021\end{array}$ & $\begin{array}{l}\text { Bulgular - İki ana tema ve on iki alt kategoriye ayrılan şikâyetlerin içerik analizi, müşterilerin } \\
\text { bankacılık hizmetlerinden faydalanırken yaşadıkları; kart kullanımı ve para transferi işlemlerinden } \\
\text { ücret alınması, kredi kartı teslimatında kurye problemi, kredi yapılandırmada ekstra masrafların } \\
\text { çıkması gibi hizmet sorunlarından dolayı rahatsız olduklarını ortaya koymuştur. Ayrıca yapılan } \\
\text { incelemeler sonucunda banka geribildirimlerinin tamamının otomatik sistem mesajı şekilde olduğu } \\
\text { tespit edilmiştir. }\end{array}$ \\
\hline $\begin{array}{l}\text { Makale Kategorisi: } \\
\text { Araştırma Makalesi }\end{array}$ & $\begin{array}{l}\text { Tartışma - Etkili şikâyet yönetimi işletmelere; memnuniyet, sadakat, e-PWOM (çevrimiçi pozitif } \\
\text { ağızdan ağıza pazarlama), olumlu marka imajı ve uzun dönemde karlılık olmak üzere çok sayıda fayda } \\
\text { sağlamaktadır. Bu bağlamda araştırma bulguları şikâyet yönetimi alanında sektöre ve literatüre yararlı } \\
\text { bilgiler sunmaktadır. }\end{array}$ \\
\hline
\end{tabular}

\section{ARTICLE INFO}

\section{Keywords:}

E-complaints

Banking sector

E-CRM

E-WOM

Content analysis

Received 9 February 2021

Revised 28 August 2021

Accepted 10 September 2021

Article Classification:

Research Article

\section{ABSTRACT}

Purpose - This study aims to analyze e-customer complaints and bank feedback from two banks, one of which is a public bank and one of which is private capital, on the sikayetvar.com forum site, and to offer suggestions to banks in the context of e-customer relationship management.

Design/methodology/approach - Content analysis was conducted to categorize and qualitatively analyze 18,018 textual complaints of similar nature. In the six-month period between July and December 2019, 7,652 complaints belonging to the state bank and 10,366 complaints belonging to a private bank were examined in detail and categorized to provide more understandable information to financial service providers.

Findings - The content analysis of the complaints divided into two main themes and twelve subcategories, shows what customers experience while benefiting from banking products and services; It has revealed that they are uncomfortable with service problems such as card usage and money transfer fees, courier problem in credit card delivery, extra charges in loan structuring. In addition, as a result of the examinations, it was determined that all of the bank feedbacks were in the form of an automatic system message.

Discussion - Effective complaint management to businesses; It provides many benefits including satisfaction, loyalty, e-PWOM (online positive word of mouth marketing), positive brand image and long-term profitability. In this context, the research findings provide useful information for the sector and the literature in the field of complaint management.

*Bu çalışma Nevşehir Hacı Bektaş Veli Üniversitesi Sosyal Bilimler Enstitüsü Finans ve Bankacılık Anabilim Dalı'nda tamamlanan “EWOM kapsamında müşteri şikâyetlerinin değerlendirilmesi: Bankacılık sektörü üzerine nitel bir araştırma" adlı yüksek lisans tezinden türetilmiştir. 


\section{GİRIŞ}

Dijitalleşen dünyada bankacıllk sektöründeki işletmeler, müşteri memnuniyetini ve beraberinde müşteri sadakatini artırma noktasında isteklidirler. Ancak birçok sektör yöneticisi müşteriyi elde tutmanın öneminin farkında olsa da müşteri geribildirimleri olarak nitelendirilen e-şikâyetlerin çözümünün mevcut müşteriyi korumadaki kritik rolünü göz ardı etmektedirler. E-şikâyetler sonucu ortaya çıkan hizmet hatalarının giderilmesi ve memnuniyetsizliğin temeline inilip çözüm üretilmesi, müşteriye değer sunmanın ve artan hizmet kalitesinin bir sonucu olarak sadakatin artmasını sağlamaktadır (Taylor ve Baker, 1994; Cho vd., 2002). Sadakat ise bankaların karlılıklarını olumlu yönde etkilemektedir. Sadık müşteriler ile uzun dönemli ilişkiler kurulmakta ve bu ilişki bazen bankanın marka savunuculuğu şeklinde devam etmektedir. Ancak Fisk vd., (1990) memnuniyetsizliğin memnuniyetten daha fazla aktarıldığını iddia etmektedir. Benzer bir şekilde Hart vd., (1990: 153) aldıkları hizmetten memnun müşterilerin deneyimlerini 6 kişiye aktardığını buna karşılık hizmet aksaklıkları yaşamış müşterilerin deneyimlerini ise ortalama 11 kişiye aktardığını ifade etmiştir. Sonraki dönemlerde yapılan birçok araştırmada da bu durumu destekleyici sonuçlar çıkmıştır (Lau ve Ng, 2001; Goldenberg vd., 2007 ) Bu bağlamda müşteri memnuniyeti ile uzun dönemli karlılık hedefleyen bankalar, şikâyet yönetimi kapsamında e-şikâyetleri titizlikle incelemeli ve çözüm sunma konusunda empatik davranmalıdır. Goodman (1999) geribildirimden ya da bankanın şikâyetlere çözüm sunma sürecinden memnun olan müşterilerin daha önce hiç sıkıntı yaşamayan müşterilere oranla yaklaşık \%8 daha sadık olduğunu tespit etmiştir.

Müşterilerin banka tercihinde kurumsal imaj önemli bir yere sahiptir. Ağızdan ağza iletişim (WOM) ise kurumsal imajın şekillenmesinde güvenilir bir bilgi kaynağı olarak görülmektedir (Yang vd., 2018; Wang vd., 2019). Son yıllarda bilgi iletişim teknolojilerinin gelişmesi ve müşterilerin dijital platformlarda varlığının artması ile birlikte banka seçim kararları elektronik WOM (e-WOM)'dan etkilenmektedir (Nair ve Radhakrishnan, 2019: 71). Bu bağlamda negatif elektronik ağızdan ağza iletişim (e-NWOM) kapsamında değerlendirilen e-şikâyetlerin bankacılık sektörü gibi hizmet endüstrilerinde potansiyel müşterileri etkileme olasılığ1 yüksektir. Bankalar mevcut müşterilerinin deneyimlerine ilişkin olumlu görüşleri ile potansiyel müşterileri etkileme konusunda fayda sağlarken negatif görüşlerden ise zarar görmektedir (Wu ve Wang 2017). Bu bağlamda olumlu görüşlerin yayılımının artması konusunda nasıl bir yol izleneceği, negatif görüşlerin ise nasıl tersine çevrileceği konusu elektronik müşteri ilişkileri yönetimi (e-CRM) özelinde değerlendirilmelidir.

Çevrimiçi ortamda müşteriler ile uzun dönemli ilişkileri tatminkar bir seviyede tutma eylemi olarak tanımlanan e-CRM (Sujitha ve Johnson, 2017) temelde internet tabanlı bir ilişkisel pazarlama modelidir (Pourmand ve Lari, 2016). İlişkiyi etkin bir şekilde yönetmek adına müşterilerin forum siteleri, web siteleri, bloglar, e-postalar gibi temas noktalarında kurdukları iletişimler sürekli olarak takip edilmeli ve bu alanlardaki interaktif eş zamanlı bilgi paylaşımı bankacılık sektöründe rekabet aracı olarak kullanılmalıdır.

Yukarıdaki bilgiler doğrultusunda bu çalışma biri kamu bankası diğeri özel banka olmak üzere iki Türk bankası özelinde sikayetvar.com sitesinde dağınık halde yer alan 18.018 şikâyeti inceleyerek araştırılan alandaki boşluğu doldurmaktadır. Araştırma ile online müşteri şikâyetlerine dayanarak bankacılık hizmetlerinden kaynaklanan sorunların net bir resmi ortaya konmaya çalışılmaktadır.

\section{LITERATÜR}

\subsection{E-Şikâyetler}

Görüşlerini online olarak ifade etmek isteyen müşterilerin sayısının artması sikayetvar.com gibi forum sitelerinin bilinirliğine fayda sağlamıştır. Ocak/2021 itibariyle ilgili sitede "banka" anahtar kelimesi ile 281.396 şikâyet kaydedilmiştir (www.sikayetvar.com.tr). Bu rakam bankacılık sektörü için e-şikâyetlerin pazarlama amaçlı ele alınması gerekliliğinin bir göstergesidir.

İnternetin, bankacılık sektöründeki şikâyetleri nasıl etkilediği konusunda az sayıda çalışma bulunmaktadır. Ekonomik büyümeye katkı sağlayan sektörler arasında bankacılık sektörünün kayda değer bir yeri olmasına (BDDK, 2020) rağmen banka müşterilerinin çevrimiçi şikâyetlerinin sınırlı sayıda araştırmacı tarafından ele alınması dikkat çekicidir. Şikâyetleri etkin bir şekilde yönetmek müşteri elde tutma ve dolaylı olarak olumlu görüş paylaşım oranını artırmaktadır (Mattila ve Mount, 2003). Potansiyel müşterileri etkileme konusunda, kötü hizmetten kaynaklanan olumsuz görüşler olarak nitelendirilen e-şikâyetler, iyi hizmet geribildirimi olan 


\section{Bozpolat - F. Çopur 13/3 (2021) 2056-2071}

olumlu görüşlerden daha etkilidir (Han vd., 2016: 1). Önceki araştırmalar hizmet aksaklıkları sonucu oluşan öfke-hayal kırıklığı gibi olumsuz duyguları deneyimleyen müşterilerin, intikam almak amacıyla e-NWOM eylemlerinde bulunma olasılığının daha yüksek olacağını göstermektedir (Wetzer vd., 2007; Gelbrich, 2010: 567). Bu nedenle bankalar hizmet süreçlerini iyileştirmek için müşteri şikâyetlerine odaklanmalıdır. Banka genel müdürlüklerinde e-CRM kapsamında şikâyet yönetimi için personel istihdam edilmeli ve bu personeller şikâyetlere sesli ya da elektronik geri dönüş yapmalıdır. Kurulan diyalogda memnuniyetsizliğin nedenleri sorulmalı ve sistem kayıtlarından sorunun neden kaynaklandığı müşteriye izah edilmelidir. Böylece sorunun kaynağını anlayan müşterilerin öfke ve devamında intikam alma duyguları azalır (Weiner, 2000). Aslında müşteriye yapılan bu açıklamalar hizmet aksaklıklarını telefi etme noktasında harcama gerektirmeyen tazminatlardır (Chebat ve Slusarczyk, 2005).

Singh (1988) çalışmasında şikâyet davranışını; ilgili işletmeye yapılan şikâyetler, birinci derece referans gruplarına yapılan şikâyetler ve bağımsız kuruluşlara iletilen şikâyetler olmak üzere üç kategoride sınıflandırmıştır. Bu sınıflandırma dijital dünya için de geçerlidir (Tyrrell ve Woods, 2004: 185). Günümüz müşterileri, bağımsız kuruluşları şikâyet çözüm sürecinde etkili ve hızlı bir kanal olarak görmektedir. Sikayetvar.com ise şikâyet davranışına aracı bağımsız kuruluşlardan biridir. Bu forum sitesi, araştırılan marka, model, sektör, ürün, hizmet gibi anahtar kelimelerle ilgili konu kapsamındaki deneyim ve fikirlere ilişkin hızlı bir tarama yapma olanağı sağlamaktadır.

Öte yandan bağımsız kuruluşlara iletilen şikâyetler, bankaların denetim altında tutamadıkları şikâyetler kategorisinde olduğundan bu şikâyetleri izlemek, ilgili işletmeye yapılan şikâyetleri izlemekten daha zordur (Yıldız Erduran ve Lorcu, 2020: 3858). Sarı (2013: 564) ve arkadaşlarının konaklama işletmelerine yapılan eşikâyetleri incelediği çalışmalarında sadece şikâyetleri izlenmenin bilgi gücü açısından yeterli olmayacağı aynı zamanda şikâyetlerin aktif bir parçası (geribildirim ile) olmanın gerekliliği vurgulanmıştır. Bu doğrultuda iletilen şikâyetler incelendikten sonra hizmet alım sürecinde yaşanan problemleri ortadan kaldıracak düzenlemeler yapılmalıdır. Bu yaklaşım fiyat rekabetinin sınırlı olduğu bankacılık sektöründe uzun dönemde karlılık ve büyüme bakımından önemlidir (Cambra-Fierro vd., 2015: 121). Bu bağlamda bu çalışma, iki banka özelinde yapılan e-şikâyetleri inceleyerek kamu ve özel bankalara hizmet aksaklıkları konusunda ipuçları ve öneriler sunmaktadır.

\subsection{Negatif E-Ağızdan Ăğıa İletişim (E-NWOM)}

Elektronik ağızdan ağza iletişim (e-WOM), müşterilerin mal ve hizmetlere ilişkin bilgi, düşünce, görüş ve deneyimlerini çevresindeki bireylere paylaşması olarak tanımlanan (Hawkins ve Mothersbaugh, 2004: 244) ağızdan ağza iletişimin (WOM) internet tabanlı versiyonudur (Jeong ve Jang, 2011: 357). E-WOM kurulan iletişimin negatif ve pozitif olmasına göre farklılaşmaktadır. Önceki araştırmalar satın alma karar sürecinde mal ve hizmetlerle ilgili olumsuz deneyimlerin paylaşılması olarak tanımlanan e-NWOM'un, mal ve hizmetlerle ilişkin olumlu görüşlerin paylaşılması olarak tanımlanan e-PWOM'dan daha etkili olduğunu göstermiştir (Arndt, 1967; Park ve Lee, 2009: 62; Yang ve Mia, 2010: 1052; Dülek, 2019: 24; İlban vd., 2021: 180). Benzer bir şekilde Anderson (1998) negatif hizmet deneyimi sonucu iletilen WOM'un \%70, pozitif hizmet deneyimi sonucu iletilen WOM'un ise \%30 etkiye sahip olduğunu tespit etmiştir. Bu bağlamda e-NWOM kapsamında değerlendirilen e-şikâyetlerin cevapsız bırakılması, müşteri memnuniyetsizliğine neden olmakla birlikte olumsuz görüş yayılımını da hızlandırmaktadır. Singh (1988)'e göre memnun olmayan müşterilerin büyük çoğunluğu, ilgili işletme ile doğrudan temasa geçmeyip markayı kullanmayı bırakma ya da çevresindeki potansiyel müşterilerin görüşlerini olumsuz yönde etkileme davranışı göstermektedir. Bu açıdan müşterilerin sözlü veya elektronik olarak şikâyette bulunması işletmeler için bir avantajdır (Barlow ve Moller, 2008: 20). Böylece işletmeler hizmet süreçlerinde yaşanan problemleri fark ederek sorunu kaynağından gidermeye çalışır. İşletmenin bu çabası ise mağduriyet yaşayan müşteriyi bir nebze olsun sakinleştirebilir. Şikâyetlere geribildirimde bulunmak mevcut müşteriyi koruma ve potansiyel müşterilerin fikirlerini yönetme üzerinde etkilidir (Halstead vd., 1993; Mitchell, 1993; Conlon ve Murray, 1996).

Sundaram vd., (1998) müşterilerin e-NWOM'a katılma nedenlerini "diğerlerini düşünme", "kaygıyı azaltma”, "intikam ve tavsiye arama" olarak sinıflandırmıştır. Bu sınıflandırmanın temelinde algılanan adalet duygusunu tatmin etme yatmaktadır. Algılanan adalet ise müşterilerin bir işletmenin faaliyetlerinin adilliğini değerlendirme biçimidir (Jung ve Seock, 2017: 23). Bu bağlamda e-şikâyetler, hizmet aksaklıkları yaşayan müşterinin adalet arama davranışının bir sonucudur. Hizmet kurtarma ya da iyileştirme davranışı olarak 


\section{Bozpolat - F. Çopur 13/3 (2021) 2056-2071}

şikâyetlere çözümler sunmak, müşteri memnuniyetini, memnuniyet sonucu oluşan tatmin ise algılanan adaleti etkilemektedir (Chang ve Chang, 2010; Gelbrich ve Roschk, 2011). Buna karşın sunulan çözüm sonrası algilanan adalet duygusu tatmin olmayan müşteriler e-NWOM'a yönelmektedir. Başka bir ifadeyle e-NWOM niyeti, müşterinin şikâyet sonrası adalet algısına bağlıdır (Blodgett vd., 1993).

Kim vd., (2009) çalışmalarında hizmet iyileştirmesi sonucu oluşan güvenin müşteri memnuniyeti ile WOM niyeti arasındaki aracılık etkisini incelemiştir. Sonuçlar güvenin, hizmet kurtarma ya da iyileştirme sonrası oluşan memnuniyet ve WOM niyeti arasında önemli bir aracı değişken olduğunu göstermiştir. Bankacılık sektöründe müşterilerle uzun süreli ilişkiler kurmak ve geliştirmek için güven önemli bir faktördür. ENWOM'a verilen tatmin edici geribildirim güven yaratmakta güven ise e-PWOM teşvik etmektedir. Müşterileri e-NWOM'a iten algısal adalet, tatmin edici olmayan geribildirim gibi nedenler üzerinde durmak ve çözüm önerilerini bu nedenler üzerine kurgulamak şikâyet yönetimi açısından önemli bir yere sahiptir.

\subsection{E-Müşteri İlişkileri Yönetimi (E-CRM)}

Web tabanlı CRM olarak da bilinen e-CRM, müşterilerle ile ilgili verilerin, elektronik ortamdaki müşteri etkileşimlerinden elde edilmesidir (Karakostas, 2005: 854). Başarılı bir e-CRM için, e-şikâyetlerden yola çıarak mevcut müşterilerin problemlerini çözme ve potansiyel müşterileri olumlu yönde etkileme, sadık müşterileri artırma amaçlarını gerçekleştirebilecek sürdürülebilir stratejiler uygulanmalıdır. Bu stratejilerin odak noktası müşteri memnuniyetidir (Cho vd., 2002). Şikâyetlerle iletilen hizmet hatalarının giderilmesi sonucu artan memnuniyet düzeyinin e-WOM'a pozitif katkısı, uzun vadede müşterilerle iyi ilişkilerin kurulabileceğini göstermektedir. Bu durum, şikâyetlere verilen tatmin edici geribildirimlerle ilgili bankaya yönelik olumlu imaj oluşabileceğini ve müşteri ile banka arasında güçlü ilişkilerin kurulabileceğini doğrulamaktadır (McCollough, 2000). Başka bir ifadeyle Clark vd., (1992: 6) çalışmalarında şikâyetlere verilen yanıtların yetersiz olmasının olumsuz imaj yaratacağını ve yaratılan bu durumu ise değiştirmenin zor olacağını belirtmişlerdir. Ayrıca etkin şikâyet yönetimi ile oluşacak güçlü ve pozitif bir imajın e-PWOM ile potansiyel müşterilerin davranışını da olumlu yönde etkileyebileceği ifade edilmiştir.

Önceki araştırmalar şikâyetleri etkin bir şekilde işleme almanın, mevcut müşterilerle ilişkileri koruma ve sadık müşteriler kazanma ile pozitif bir şekilde ilişkili olduğunu ve karlılı̆̆ı uzun dönemde etkilediğini göstermiştir (Tax vd., 1998; Johnston, 2001; Homburg ve Fürst, 2005; Rothenberger vd., 2008). Karlılı̆̆ını ve pazar payını artırmak isteyen bankalar hizmet aksaklıklarıyla ilgili e-şikâyetleri yönetebilmek adına emek, zaman ve para harcamaktadır. Buna, memnun olmayan müşterilerin problemleri ile ilgilenen çağrı merkezi personellerine sorunun en kısa sürede düzeltilmesi için hizmet içi eğitim vermek ve personeli bu konuda teşvik etmek için memnun müşteri geribildirimlerini ücretlendirme politikasında bir kriter olarak kullanmak örnek olarak verilebilir.

Stauss ve Seidel (2004)'e göre şikâyet yönetimi CRM'in kalbidir. Ancak bankalar gerek tüm müşteri şikâyetlerini önleyememelerinden gerekse çevrimiçi ortamdaki bilgi kirliliğinden şikâyet yönetimini etkin bir şekilde yapamamaktadırlar. Şikâyetleri işlemenin ve tatmin edici geribildirimlerde bulunmanın e-CRM üzerindeki etkisi büyük ölçüde önemli olduğundan bankalar e-şikâyetlerini sürekli ve hızlı bir şekilde yönetmeye yardımcı olacak bilgi teknolojilerini süreçlerine entegre edebilirler. Etkili e-CRM yapabilmek için şikâyet kanalları akıllı iş süreçleri ile uyumlaştırıp yönetilebilir (Zaby ve Wilde, 2018).

Bankacılık sektöründe rekabet şiddetlidir ve yeni dijital teknolojiler nedeniyle rakipler birbirlerinin mal ve hizmet stratejilerini kolaylıkla kopyalayabilmektedir. Ancak müşterilerle olan diyaloglar taklit edilememektedir (Maurer ve Schaich, 2011). Bu bağlamda bankaların rekabet gücü, mevcut ve potansiyel müşterilerinin dinamik bir şekilde değişen ihtiyaç ve taleplerini anlamakla doğru orantılıdır (Ravi vd., 2017: 786). E-şikâyetler müşterilerin taleplerini ilettiği doğrudan iletişim kanalarıdır. Şikâyetlerin değerlendirilmesini ve müşterilerle iyi ilişkiler kurmayı sağlayan çözümler sunulmasını kapsayan e-CRM, müşterilerin anlaşılması, yöneticilerin ise sistemlerinde gerekli değişiklikleri yapması konusunda yararlı bilgiler sunmaktadır. E-CRM, rekabette bir adım önde olmak isteyen bankaların odak noktası olmalıdır.

Toparlamak gerekirse, bankalar uzun dönemde sektördeki konumlarını korumak ve iyileştirmek için sadakat bağları ile güçlendirilmiş müşteri ilişkileri yaratmalıdır. Bu ise etkili şikâyet yönetimi ile mümkün olabilmektedir. Başta çevrimiçi şikâyetler olmak üzere tüm temas noktalarında şikâyetlerin dikkate alınması ve çözüm önerileri sunulması negatif ağızdan ağıza iletişimi azalmasına katkı sağlayabilir. Bu bağlamda 


\section{Bozpolat - F. Çopur 13/3 (2021) 2056-2071}

mevcut çalışma bankalara iletilen e-şikâyetleri sınıflandırarak sistem iyileştirmeleri konusunda öneriler sunmaktadir.

\section{METODOLOJI}

\subsection{Araştırmanın Amacı ve Önemi}

Müşteri şikâyetleri üzerine yapılan önceki çalışmaların çoğu, konaklama, yeme-içme ve ulaşım hizmetlerine ilişkin online müşteri yorumlarından yola çıkarak hizmet alım sürecinde yaşanan sorunları değerlendirmektedir (Cho vd., 2002; Rothenberger vd., 2008; Maurer ve Schaich, 2011; Jeong ve Jang, 2011). Finansal hizmet sağlayıcılarının verdikleri hizmetten memnun olmayan müşterilerin çevrimiçi ortamda şikâyetlerini nasıl dile getirdikleri ve hizmet kurtarma eylemi olarak değerlendirilen geribildirimlerin niteliği hakkında sınırlı sayıda çalışma bulunmaktadır. Eser vd., (2016) banka şikâyetlerini hizmet pazarlaması ve markalaşma özelinde incelerken, Yıldız Erduran ve Lorcu (2020) bankalara yönetilen şikâyetleri veri madenciliği tekniğiyle araştırmıştır. Bu araştırmaların bulguları literatüre katkı sağlamaktadır. E-şikâyetlerin nedenleri ve çözümleri üzerine çalışmalar yapmak alan yazınını zenginleştirecektir. Bu bağlamda mevcut çalışma, bankalara yöneltilen e-şikâyetleri ve bu şikâyetlere sunulan banka geribildirimlerini, biri kamu diğeri özel sermayeli banka olmak üzere iki banka odağında inceleyerek bankalara e-müşteri ilişkileri yönetimi bağlamında öneriler sunmayı amaçlamaktadır.

\section{2. Örneklem ve Veri Toplama}

Bankacılık sektöründeki online şikâyetleri inceleyen çalışmaların azlığı, yazarları bağımsız bir çevrimiçi şikâyet sitesine (www.sikayetvar.com) iletilen şikâyetleri değerlendirmeye yöneltti. Araştırmanın örneklemi, biri kamu diğeri özel sermayeli banka olmak üzere bu iki finansal hizmet sağlayıcısının hizmetlerinden memnun olmayan ve sikayetvar.com sitesine memnuniyetsizliğini ileten müşterilerden oluşmaktadır. Bu eşikâyet sitesi, tüketicilerce en çok bilinen ve tanınan bir site olması (bireysel üye sayısı 6.334.123 kişi), markaların kolayca geribildirimde bulunmasına olanak tanıyan fonksiyonel tasarımının olması (çözülen şikâyet sayısı 1.068.192), Türkiye'nin ilk ve en eski şikâyet sitesi olması nedenlerinden ötürü seçilmiştir (www.sikayetvar.com). Bankacilık sektörünün seçilmesinde mevcut ve potansiyel müşteri kitlesinin fazla ve bu kitlenin şikâyetlerden etkilenebilecek olması dikkate alınmıştır. Kamu ve özel sermayeli banka kategorisinde en fazla şikâyeti alan bankalar örnekleme dahil edilmiştir.

1 Temmuz 2019 - 31 Aralık 2019 tarihleri arasında çok sayıda anahtar kelimelerle ilgili şikâyet sitesi tarafından gruplandırılmış 18 bankayı kapsayan toplam 59.313 şikâyet tespit edilmiştir. Altı aylık dönemde araştırma örneklemine dahil edilen kamu bankasının 7.652, özel sermayeli bankanın 10.366 olmak üzere toplam 18.018 şikâyetin olduğu belirlenmiştir. Şikâyet verileri araştırmacılardan biri tarafından bizzat toplanmıştır. Kullanılan şikâyet verileri kamuoyuna açık ikincil veriler olduğundan etik kurul iznine gerek duyulmamıştır. Sikayetvar.com sitesi üzerinden ikincil nitel veri düzeyinde toplanan şikâyetleri analiz edebilmek için şikâyetler, belirli temalara ve kategorilere ayrılarak nicel olarak ifade edilmiştir. Şikâyetler "bankanın sunmuş olduğu hizmetler ve ürünler" ve "müşteri temsilcisi" olmak üzere iki temaya ayrılmıştır. Bankanın sunmuş olduğu hizmetler ve ürünler temasının altında; kart ve hesap işlemleri, kredi, online işlemler, para transferi, altın hesabı, ATM, borsa- yatırım, kiralık kasa, ortak ATM ve diğer olmak üzere on farklı ana kategori oluşturulmuştur. Müşteri temsilcisi teması ise "çağrı merkezi" ve "şube personeli" olmak üzere iki ana kategoriye ayrılmaktadır. Belirlenen ana kategorilerin altında alt kategoriler yer almaktadır. Bunlar ise; kart ve hesap işlemleri için; hesap-banka kartı, hesap-kart blokesi, kredi kartı, kart teslimatı-kurye sorunu, nakit avans-KMH ve ücret iadesidir. Kredi ana kategorisi için; kullanılan ve kullanılmak istenen kredi, kredi yapılandırılması ve ücret iadesidir. Online işlemler kategorisi için; internet bankacılığı ve mobil bankacılıktır. Para transferi için; EFT, havale, EFT-havale için alınan ücretler, western unionswiftdir.

\subsection{Veri Analizi}

Araştırmada metinsel veri niteliğindeki şikâyetleri belirli tema, ana ve alt kategorilere ayırabilmek için içerik analizi yapılmıştır (Vaismoradi vd., 2016: 101). İçerik analizi ise birbirine benzeyen çok sayıda verinin sınıflandırılarak okuyucuların algılayabileceği bir hale getirildiği bir analiz şeklidir (Yıldırım ve Şimşek, 2018: 242-243). Araştırmada Downe ve Womboldt (2009: 315) tarafından geliştirilen içerik analizi aşamalarından yararlanılmıştır. Analizin ilk aşamasında araştırma evreni (sikayetvar.com) belirlenmiş ve evrenden iki bankaya ilişkin şikâyetler seçilerek analiz birimleri oluşturulmuştur. Analiz birimleri olan ilgili bankalara 
ilişkin şikâyetler değerlendirilirken kategoriler oluşturularak tanımlamalar yapılmıştır. Kategori tanımlamalarının geçerliği ve güvenirliği test edilmiştir. Nitel araştırmalarda güvenirlik, kategori tanımlamaları yapan araştırmacılar arasındaki uyum ile ilişkilidir. Güvenirliği test etmek için kappa analizinden yararlanılmaktadır. Kappa analizi, içeriklerin kategorileştirilmesinde birden fazla araştırmacı arasındaki uyumu ölçen analizdir (Kılıç, 2015: 142). Bu çalışmada kategorileştirme işlemi tek araştırmacı tarafından yapıldığından kappa analizine gerek duyulmamıştır. Geçerlikte ise kategorileştirme işlemini yapan araştırmacıyı kontrol eden uzmanlar olmalıdır. Bunun için ise oluşturulan kategoriler, iyi eğitimli iki uzman tarafından düzenli aralıklarla kontrol edilmiştir (Kassarjian, 1977: 9). 18.018 şikâyete ilişkin kategorileştirme işlemi bittikten sonra geçerlik ve güvenirlik yeniden değerlendirilmiştir. Yapılan bu işlemler sonucunda temalar, ana ve alt kategoriler belirlenerek müşterilerin genel olarak nelerden şikâyetçi oldukları tespit edilmiştir. Kategorilerdeki şikâyetlere verilen cevaplar ve tüketici teşekkürleri doğrultusunda bankaların bu şikâyetleri ne derece dikkate aldığı incelenmiştir. Ayrıca şikâyetlerin ve teşekkürlerin hangi ana ve alt kategorileri kapsadığı belirlenmiştir.

\subsection{Bulgular}

Yapılan incelemeler sonucunda ilgili tarih aralığında bankalara çeşitli kategorilerde toplam 17.918 şikâyet iletilmiştir. Bu şikâyetlerin temalara, ana ve alt kategorilere göre altı aylık dağılımı Tablo 1 ve Tablo 2'de gösterilmiştir. Tablo 1 incelendiğinde, kamu bankası özelinde en fazla şikâyet edilen konunun, bankanın sunmuş olduğu hizmetler ve ürünler teması altında bulunan kategorilerde olduğu görülmektedir. Tablo 1'e göre Ziraat Bankası altı aylık dönemde 1401 şikâyetle en fazla şikâyeti Ağustos ayında almıştır. Ağustos ayında yapılan şikâyetler incelendiğinde "kredi" ana kategorisinde bulunan "kredi yapılandırma" alt kategorisinin şikâyet sayısı (625) dikkat çekmektedir. Bir önceki aya göre bu aydaki artışın kredi faiz oranlarındaki düşüşle ilişkili olduğu söylenebilir. Şikâyetlerin ayrıntılı içerik analizleri sonucunda düşen faiz oranlarından dolayı müşterilerin kullandıkları kredilerde yapılandırmaya gittikleri gözlenmiştir. Bu dönemde yapılan şikâyetler, banka ile iletişime geçildiği fakat bankanın yapılandırma imkanı tanımadığı yönündedir. Müşteriler yapılandırabileceklerine güvenerek kredi çektiklerini ve yapılandıramadıkları için banka ile iletişimlerini kesmeyi düşündüklerini dile getirmişlerdir. Bazı müşterilere bu dönemde kredi faiz indiriminden dolayı bankalarda yoğunluk olduğu banka çalışanları tarafından söylenmiştir. Bu yüzden bankaların her müşteriye cevap veremedikleri ve yardımcı olamadıkları düşünülmektedir. Tablo 1'e bakıldığında takip eden aylarda kredi yapılandırma alt kategorisindeki şikâyetlerin belirgin seviyede azaldığı görülmektedir.

Eylül ayına bakıldığında "kart ve hesap işlemleri" ana kategorisi "kart teslimatı-kurye sorunu" alt kategorisindeki şikâyetlerin arttığı gözlenmiştir. Bu artışa üniversite öğrencilerinin KYK bursuna/kredisine başvurmaları ve kartlarını teslim alma konusunda sıkıntı yaşamaları neden olmuştur. İncelemeler sonucunda şikâyetlerin çoğunluğunun kredi kartı teslimatında gecikmelerden, kargo elemanlarının adrese teslimde kart sahibinin evde olmadığı gerekçesiyle teslim edemedikleri ancak müşterilerin evde olduklarını iddia etmelerinden kaynaklandığı tespit edilmiştir. Bankanın sunmuş olduğu hizmetler ve ürünler teması, online işlemler ana kategorisi altında yer alan mobil bankacıllk alt kategorisindeki şikâyetler kasım ayında diğer aylardaki şikâyet ortalamasının iki katına çıkmıştır. Genel olarak şikâyetlerde, mobil bankacılık uygulamasının işleyişi ile ilgili problemler dile getirilmiştir. Mobil bankacılık sistemleri internet ağlarından ve alt yapı sorunlarından dolayı müşterilere sıkıntı yaşatabilmektedir. 
C. Bozpolat - F. Çopur 13/3 (2021) 2056-2071

Tablo 1. Ziraat Bankasına İletilen Şikâyetlerin Konu Dağılımı

\begin{tabular}{|c|c|c|c|c|c|c|c|}
\hline KATEGORİLER & Temmuz & 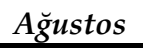 & Eylül & Ekim & Kasim & Aralık & TOPLAM \\
\hline $\begin{array}{l}\text { Bankanın Sunmuş Olduğu Hizmetler ve } \\
\text { Ürünler }\end{array}$ & 860 & 1401 & 1310 & 1060 & 1144 & 1130 & 7005 \\
\hline KART VE HESAP İŞLEMLERİ & 498 & 415 & 636 & 545 & 633 & 740 & 3467 \\
\hline - Hesap-Banka Kartı & 131 & 101 & 148 & 170 & 155 & 163 & 868 \\
\hline - Hesap- Kart Blokesi & 76 & 97 & 102 & 94 & 80 & 128 & 577 \\
\hline - Kredi kartı & 105 & 69 & 51 & 78 & 143 & 140 & 586 \\
\hline - Kart Teslimat1- Kurye Sorunu & 22 & 10 & 190 & 50 & 44 & 57 & 373 \\
\hline - Nakit Avans- KMH & 74 & 72 & 90 & 65 & 85 & 119 & 505 \\
\hline • Ücret İadesi & 90 & 66 & 55 & 88 & 126 & 133 & 558 \\
\hline \multicolumn{8}{|l|}{ KREDİ } \\
\hline - Kullanılan/Kullanılmak & 82 & 694 & 351 & 177 & 150 & 149 & 1603 \\
\hline Kredi & 60 & 44 & 65 & 69 & 90 & 63 & 391 \\
\hline - Kredi Yapılandırması & 14 & 625 & 258 & 74 & 26 & 19 & 1016 \\
\hline • Ücret İadesi & 8 & 25 & 28 & 34 & 34 & 67 & 196 \\
\hline ONLINNE İŞLEMLER & 45 & 57 & 63 & 66 & 130 & 57 & 418 \\
\hline - İnternet Bankacıllğ 1 & 22 & 24 & 19 & 29 & 48 & 18 & 160 \\
\hline • Mobil Bankacılık & 23 & 33 & 44 & 37 & 82 & 39 & 258 \\
\hline PARA TRANSFERİ & 54 & 61 & 89 & 79 & 78 & 93 & 454 \\
\hline$\bullet$ EFT & 10 & 8 & 2 & 8 & 16 & 34 & 78 \\
\hline - Havale & 4 & 1 & 3 & 8 & 5 & 21 & 42 \\
\hline • EFT-Havale Ücreti & 36 & 45 & 69 & 54 & 49 & 30 & 283 \\
\hline - Western Union-Swift & 4 & 7 & 15 & 9 & 8 & 8 & 51 \\
\hline ALTIN HESABI & 4 & 4 & 7 & 8 & 6 & 9 & 38 \\
\hline ATM & 81 & 74 & 82 & 101 & 70 & 74 & 482 \\
\hline BORSA- YATIRIM & 7 & 0 & 0 & 5 & 0 & 11 & 23 \\
\hline KİRALIK KASA & 0 & 2 & 6 & 1 & 3 & 2 & 14 \\
\hline ORTAK ATM & 48 & 47 & 49 & 52 & 53 & 52 & 301 \\
\hline DİĞER & 41 & 47 & 27 & 26 & 21 & 43 & 205 \\
\hline Müşteri Temsilcisi & 102 & 123 & 110 & 127 & 74 & 111 & 647 \\
\hline ÇAĞRI MERKEZİ & 31 & 25 & 25 & 18 & 20 & 40 & 159 \\
\hline ŞUBE PERSONELİ & 71 & 98 & 85 & 109 & 54 & 71 & 488 \\
\hline TOPLAM & 962 & 1524 & 1420 & 1187 & 1218 & 1341 & 7652 \\
\hline
\end{tabular}

Tablo 1'e bakıldığında "kart ve hesap işlemleri" ana kategorisinde "kart teslimatı ve kurye sorunu" alt kategorisi hariç diğer tüm kategorilerde altı aylık dönemde benzer sayıda şikâyette bulunulmuştur. Tablo 1'e göre altı aylık dönemde hesap-banka kartı alt kategorisinde en fazla şikâyet Ekim ayında gerçekleşmiştir. Aynı ayda müşteri temsilcisi teması altında yer alan şube personeli ana kategorisinde bir önceki ve bir sonraki aylara göre şikâyetlerde artış yaşanmıştır. Bu durum, hesap-banka kartı işlemlerinin büyük çoğunluğunun banka şubesinde gerçekleşmesi nedeniyle hizmet alım sürecinde şube personelinin müşterileri mutsuz edecek tutum ve yaklaşımlarda bulunması ile açıklanabilir. Bununla birlikte şubelere ulaşılamaması, şube temsilcilerine gerektiğinde iletişim kurulamaması ve şubelerde bulunan güvenlik personellerinin tavırları müşterileri rahatsız eden diğer unsurlardır. Gişe çalışanlarının yavaş işlem yapmaları ve saatlerce sıra bekleniyor oluşu ise çokça şikâyet edilen bir diğer konudur.

Altın hesabı, borsa-yatırım hesabı ve kiralık kasa işlemleri en az şikâyet alan ana kategoriler olarak dikkat çekmektedir. Altın hesabı için yapılan şikâyetler, alış-satış fiyatları arasındaki farklılıktan; borsa-yatırım hesabı kısmında bulunan şikâyetler hisse senedi alım-satımı sırasında işlemlerin gerçekleştirilememesinden ve sistemin kitlenip tekrar açılmamasından; kiralık kasa işlemlerinde ise şikâyetler kasa ücretinden kaynaklanmaktadır.

Diğer ana kategorisinde ise; OGS-HGS işlemlerinden kaynaklı sorunlar, bankayla yapılan anlaşmalar kapsamında vaad edilen promosyonların ödenmemesi, BES ile ilgili sorunlar, bankayla ilgili teknik aksaklıklar, yansıtılan kur farkları, yanlış telefon numaralarına giden mesajlar, borç olmamasına rağmen sicilde gözüken borçlar şeklinde şikâyetler yer almaktadır. 


\section{Bozpolat - F. Çopur 13/3 (2021) 2056-2071}

Yukarıda ayrıntılarına değinilen şikâyetlere ek olarak ilgili tarihlerde toplam 943 şikâyet çözümlenmiş ve müşteriler tarafından bankaya teşekkür edilmiştir. Sitede yer alan şikâyetler ortalama 17 saat içerisinde sistemsel olarak cevaplanmaktadır. Çözümlenen şikâyet sayısının toplam şikâyet sayısına oranı ise \%12,32 olarak belirlenmiştir. Çözüme ulaştırılan ve hala sitede yayınlanan şikâyet sayısı toplamda 511'dir. 432 şikâyet ise çözüme ulaştıııldıktan sonra siteden kaldırılmıştır. Bunun yanı sıra 187 şikâyet ise çözülmeden siteden kaldırılmıştır. Geriye kalan şikâyetlerin çözülüp çözülmediği ise belirsizdir. Ziraat Bankasının e-şikâyetler özelinde müşteri memnuniyet oranı ise $\% 38^{\prime}$ dir. Şikâyetleri sistem mesajıyla otomatik olarak cevaplamalarına rağmen cevaplanma oranı $\% 78^{\prime}$ dir.

Özel sermayeli bir banka olan Garanti BBVA bu çalışmada şikâyetleri incelenen bir diğer bankadır. Altı aylık dönemde yapılan şikâyet sayıları Tablo 2'de gösterilmektedir. Tablo 2'de görüldügüü üzere Garanti BBVA en fazla şikâyeti Temmuz ayında almıştır. Banka Haziran 2019 tarihinden itibaren İspanya ile ortak olmuş ve bankanın ismi Garanti BBVA olarak değişmiştir. İspanya ile yapılan ortaklığın sonrasında görülen şikâyet sayısı bankanın kendi içinde bir işleyiş sıkıntısı yaşayıp yaşamadığı yönünde bir soru işareti oluşturmaktadır. Haziran ayında bir ortaklığa imza atan bankanın Ağustos ayında altı aylık dönemin en az şikâyetini alması bu ortaklığın banka işleyişini olumlu yönde etkilediğini göstermektedir.

Tablo 2'ye göre kart ve hesap işlemleri ana kategorisindeki şikâyetlerin büyük bir kısmını "kredi kartı" ve "ücret iadesi" alt kategorilerindeki şikâyetler oluşturmaktadır. Her iki kategoride aylık olarak benzer sayıda şikâyet iletilmiştir. Kredi kartı alt kategorisindeki şikâyetlerin içeriklerine bakıldığında şikâyetlerin banka bünyesinde yer alan kredi kartlarının çeşitliliği ve sayı ile ilgili olduğu görülmüştür. Farklı özelliklere sahip kartların vaad edilen avantajları sağlamaması, kartlar için kullanım ücreti alınması, taksitlendirme noktasında problemler yaşanması bu kategorideki şikâyetlerin odak noktalarıdır. Ücret iadesi kategorisi, hesap-banka ve kredi kartı için çekilen kullanım bedellerinin, kartlardan çekilen fazla taksit tutarlarının, olması gerekenden fazla yapılan bütün ödemelerin iade edilmesi aşamalarında yaşanan şikâyetleri kapsamaktadır.

Bir diğer dikkat çeken şikâyet kategorisi Nakit avans-KMH (kredili mevduat hesabı) alt kategorisidir. Tablo 2'de Temmuz ayında sonraki aylara oranla çok fazla şikâyet aldığı görülmektedir. Bu şikâyetlerin genelinde, nakit avansa başvurulmadığı halde banka tarafından nakit avans hesabı açıldığı, çekilen nakit avans için çok yüksek faiz oranlarının uygulandığı vurgulanmaktadır. Giderek azalan nakit avans-KMH şikâyetleri ise bankanın bu konuda yapılan şikâyetleri çözüme ulaştırmak için çalışmalar yaptığını göstermektedir.

Aralık ayında kullanılan ve kullanılmak istenen krediler alt kategorisinde bir şikâyet artışı gözlenmiştir. Bunun nedeni ise müşterilerin kredi taleplerine geç dönüş yapılması, çözüm odaklı yaklaşılmaması, sürekli ekstra belge istenmesi, kredi almak için bazı sigortaların zorunlu tutulması, sonradan ilave masrafların çıkartılması, ödemeleri bitmiş krediler için kredi kapatma masrafı talep edilmesi gibi şikâyetlerdir.

Tablo 2. Garanti BBVA Şikâyetlerinin Konu Dağılımı

\begin{tabular}{|c|c|c|c|c|c|c|c|}
\hline KATEGORİLER & Тетmuz & Ă̆ustos & Eylül & Ekim & Kasım & Aralık & TOPLAM \\
\hline $\begin{array}{l}\text { Bankanın Sunmuş Olduğu Hizmetler } \\
\text { ve Ürünler }\end{array}$ & 1852 & 1220 & 1301 & 1326 & 1571 & 1780 & 9050 \\
\hline $\begin{array}{l}\text { KART VE HESAP İŞLEMLERİ } \\
\text { - Hesap- Banka Kartı } \\
\text { - Hesap-Kart Blokesi } \\
\text { - Kredi Kartı } \\
\text { - Kart Teslimatı } \\
\text { - Kurye Sorunu } \\
\text { - Nakit Avans- KMH } \\
\text { - Ücret İadesi }\end{array}$ & $\begin{array}{l}1457 \\
107 \\
88 \\
453 \\
24 \\
263 \\
522\end{array}$ & $\begin{array}{l}894 \\
49 \\
68 \\
313 \\
32 \\
27 \\
405\end{array}$ & $\begin{array}{l}953 \\
91 \\
61 \\
391 \\
45 \\
34 \\
331\end{array}$ & $\begin{array}{l}909 \\
82 \\
69 \\
346 \\
62 \\
39 \\
311\end{array}$ & $\begin{array}{l}1156 \\
78 \\
85 \\
461 \\
57 \\
31 \\
444\end{array}$ & $\begin{array}{l}1300 \\
116 \\
74 \\
466 \\
66 \\
21 \\
557\end{array}$ & $\begin{array}{l}6669 \\
523 \\
445 \\
2430 \\
286 \\
415 \\
2570\end{array}$ \\
\hline $\begin{array}{l}\text { KREDİ } \\
\text { - Kullanılan/Kullanılmak İstenen } \\
\text { Kredi } \\
\text { - Kredi Yapılandırması } \\
\text { - Ücret İadesi }\end{array}$ & $\begin{array}{l}127 \\
95 \\
11 \\
21\end{array}$ & $\begin{array}{l}81 \\
53 \\
15 \\
13\end{array}$ & $\begin{array}{l}97 \\
54 \\
28 \\
15\end{array}$ & $\begin{array}{l}112 \\
73 \\
22 \\
17\end{array}$ & $\begin{array}{l}137 \\
70 \\
47 \\
20\end{array}$ & $\begin{array}{l}190 \\
127 \\
46 \\
17\end{array}$ & $\begin{array}{l}744 \\
472 \\
169 \\
103\end{array}$ \\
\hline
\end{tabular}


ONLİNE İSLEMLER

- İnternet Bankacılığ

- Mobil Bankacilık

PARA TRANSFERI

- EFT

- Havale

- EFT-Havale Ücreti

- Western Union-Swift

\begin{tabular}{lllllll}
\hline 27 & 41 & 41 & 62 & 32 & 72 & 275 \\
12 & 6 & 21 & 22 & 3 & 17 & 81 \\
15 & 35 & 20 & 40 & 29 & 55 & 194 \\
\hline 70 & 52 & 61 & 71 & 78 & 75 & 407 \\
32 & 8 & 29 & 9 & 12 & 24 & 114 \\
11 & 4 & 9 & 11 & 3 & 10 & 48 \\
13 & 29 & 12 & 38 & 42 & 25 & 159 \\
14 & 11 & 11 & 13 & 21 & 16 & 86 \\
& & & & & & \\
\hline 2 & 0 & 4 & 7 & 1 & 4 & 18 \\
59 & 58 & 75 & 61 & 82 & 59 & 394 \\
3 & 1 & 5 & 6 & 4 & 5 & 24 \\
2 & 1 & 1 & 0 & 0 & 0 & 4 \\
7 & 6 & 7 & 7 & 5 & 10 & 42 \\
98 & 86 & 57 & 91 & 76 & 65 & 473 \\
\hline $\mathbf{2 1 0}$ & $\mathbf{2 1 3}$ & $\mathbf{2 1 0}$ & $\mathbf{2 1 5}$ & $\mathbf{2 0 9}$ & $\mathbf{2 5 9}$ & $\mathbf{1 3 1 6}$ \\
58 & 79 & 63 & 76 & 94 & 128 & 498 \\
152 & 134 & 147 & 139 & 115 & 131 & 818 \\
\hline $\mathbf{2 0 6 2}$ & $\mathbf{1 4 3 3}$ & $\mathbf{1 5 1 1}$ & $\mathbf{1 5 4 1}$ & $\mathbf{1 7 8 0}$ & $\mathbf{2 0 3 9}$ & $\mathbf{1 0 3 6 6}$ \\
\hline
\end{tabular}

ALTIN HESABI

ATM

BORSA- YATIRIM

KİRALIK KASA

ORTAK ATM

DİĞER

Müşteri Temsilcisi

ÇAĞRI MERKEZI

ŞUBE PERSONELI

TOPLAM

Altın hesabı ana kategorisinde müşteriler, altın alım-satımı esnasında yaşanan sistemsel sorunlardan, borsayatırım ana kategorisinde canlı takibin ve hisse satımının yapılamamasından ve takas adı altında kesilen ücretlerden rahatsızlık duyduklarını ifade etmişlerdir. Kiralık kasa hizmeti ana kategorisinde ise kiralık kasa ücretlerinin aylık olarak değil de yıllık olarak tahsil edilmesinden şikâyetçi olduklarını iletmişlerdir.

Diğer ana kategorisinde ise, Garanti kariyer'e üye olamama, kariyer sayfasına girişte yaşanan sorunlar, işe alım mülakatı ve online sınav aşamasında karşılaşılan sorunlar, garanti pos cihazlarından kaynaklı problemler, reklamlarda vaad edilen promosyonların ve avantajların uygulanmaması, yanlış mesaj gönderimi, HGS-OGS sorunu vb. şikâyetler yer almaktadır.

Tablo 2'ye bakıldığında müşteri temsilcisi ana teması altında yer alan çağrı merkezi ve şube personeli ana kategorilerindeki şikâyet sayıları dikkat çekmektedir. Çağrı merkezi çalışanları için yapılan şikâyetler, çalışanların ilgisizliği, bilgisizliği ve sorunlara empatik yaklaşamamalarından kaynaklanmaktadır. Şube personelinde ise genel olarak personelin tavır ve davranışlarından kaynaklanan bir memnuniyetsizlik dile getirilmiştir.

Banka geribildirimleri incelendiğinde belirlenen tarih aralığında toplam 541 şikâyet çözümlenmiş ve müşteriler tarafından bankaya teşekkür mesajı iletilmiştir. Her şikâyet ortalama 9 saat içinde sistemsel olarak cevaplanmaktadır. Çözümlenen şikâyet sayısının toplam şikâyet sayısına oranı ise $\% 5,22$ olarak belirlenmiştir. Çözüme ulaştırılan ve hala sitede yer alan şikâyet sayısı 208' dir. 333 şikâyet ise çözümlendikten sonra siteden kaldırılmıştır. Çözümlenerek kaldırılan şikâyetlerin yanı sıra herhangi bir çözüme ulaşmadan kaldırılan şikâyet sayısı ise $60^{\prime}$ dir. Geriye kalan şikâyetlerin ise çözüm sürecinde hangi aşamada oldukları belirsizliğini koruyan bir durum olarak devam etmektedir. Bankanın memnuniyet oranı ise \%37'dir. Mesajların sistemsel olarak cevaplanmasından dolayı sitede yer alan şikâyetlerin cevaplanma oranları \%100 olarak belirtilmiştir.

Tablo 1 ve Tablo 2' de bankalara ilişkin şikâyet sayıları ve kategorileri ayrıntılı olarak gösterilirken Tablo 3'te şikâyetler yüzdesel olarak ifade edilmiş ve karşılaştırmalar yapılmıştır. Tablo 3'e bakıldığında her iki bankaya iletilen şikâyetlerin büyük çoğunluğunun kart ve hesap işlemleriyle ilgili olduğu görülmektedir. Ziraat Bankasına iletilen şikâyetlerin \%45,33'ü, Garanti BBVA'ya iletilen şikâyetlerin ise \%64,35'i bu kategorideki şikâyetlerden oluşmaktadır. İki banka karşılaştırıldığında Garanti BBVA'nın şikâyet yüzdesinin Ziraat Bankasına oranla \%19,02 daha fazla olduğu tespit edilmiştir. Bu fazlalığa Garanti BBVA'nın kredi kartı ve ücret iadesi konusunda müşterileriyle yaşadığı problemlerin neden olduğunu söylemek mümkündür. Kredi kartı şikâyetleri bakımından Garanti BBVA, Ziraat Bankasına oranla \%15,77; ücret iadesi şikâyetleri bakımından ise \%17,51 oranla daha fazla şikâyet almıştır. Şikâyetlerin içerik analizi sonucunda Garanti Bankasının kart çeşitliliğinin fazla olması ile ilişkili olarak ücret iadesi şikâyetlerinin paralel bir şekilde arttığı söylenebilir. Kısa süreli işlemlerde yaşanan bu problemlerin çözümü, müşteri memnuniyetini artırarak uzun 


\section{Bozpolat - F. Çopur 13/3 (2021) 2056-2071}

vadede müşteri sadakatinin oluşmasına ve karlılığın artmasına fayda sağlamaktadır. Ancak bankaların çözümlenen şikâyet sayılarının toplam şikâyet sayısına oranları Garanti BBVA için \%5,22 Ziraat Bankası için ise \%12,32' dir. Her ne kadar Ziraat Bankası oransal olarak çözüm süresinde daha iyi görünse de bu oranlar her iki banka için de düşüktür. Başarılı bir e-CRM ile birlikte bu oranları artırmak için sorunları etkin bir şekilde çözüme kavuşturacak stratejiler geliştirilmeli ve uygulamaya koyulmalıdır.

Tablo 3. Ziraat Bankası ve Garanti BBVA'nın Şikâyet Sayıları ve Yüzdeleri

\begin{tabular}{|c|c|c|c|c|}
\hline KATEGORİLER & $\begin{array}{l}\text { Ziraat } \\
\text { Bankası } \\
\text { Şikâyet } \\
\text { Sayısı }\end{array}$ & $\begin{array}{l}\text { Ziraat Bankası } \\
\text { Şikâyet } \\
\text { Yüzdesi }\end{array}$ & $\begin{array}{l}\text { Garanti BBVA } \\
\text { Şikâyet Sayısı }\end{array}$ & $\begin{array}{l}\text { Garanti BBVA } \\
\text { Şikâyet } \\
\text { Yüzdesi }\end{array}$ \\
\hline $\begin{array}{l}\text { Bankanın Sunmuş Olduğu } \\
\text { Hizmetler ve Ürünler }\end{array}$ & 7005 & 91,54 & 9050 & 87,30 \\
\hline KART VE HESAP İŞLEMLERİ & 3467 & 45,33 & 6669 & 64,35 \\
\hline • Hesap-Banka Kartı & 868 & 11,33 & 523 & 5,05 \\
\hline - Hesap-Kart Blokesi & 577 & 7,57 & 445 & 4,29 \\
\hline - Kredi Kart1 & 586 & 7,67 & 2430 & 23,44 \\
\hline - Kart Teslimat1- Kurye Sorunu & 373 & 4,87 & 286 & 2,76 \\
\hline - Nakit Avans- KMH & 505 & 6,61 & 415 & 4,00 \\
\hline • Ücret İadesi & 558 & 7,28 & 2570 & 24,79 \\
\hline KREDİ & 1603 & 20,94 & 744 & 7,17 \\
\hline $\begin{array}{l}\text { • Kullanılan/Kullanılmak } \\
\text { İstenen Kredi }\end{array}$ & 391 & 5,10 & 472 & 4,55 \\
\hline - Kredi Yapılandirması & 1016 & 13,27 & 169 & 1,63 \\
\hline • Ücret İadesi & 196 & 2,57 & 103 & 0,99 \\
\hline ONLİNE İŞLEMLER & 418 & 5,47 & 275 & 2,65 \\
\hline • İnternet Bankacılığı & 160 & 2,10 & 81 & 0,78 \\
\hline - Mobil Bankacılık & 258 & 3,37 & 194 & 1,87 \\
\hline PARA TRANSFERİ & 454 & 5,94 & 407 & 3,92 \\
\hline$\bullet$ EFT & 78 & 1,03 & 114 & 1,10 \\
\hline - Havale & 42 & 0,54 & 48 & 0,46 \\
\hline • EFT-Havale Ücreti & 283 & 3,69 & 159 & 1,53 \\
\hline • Western Union-Swift & 51 & 0,68 & 86 & 0,83 \\
\hline ALTIN HESABI & 38 & 0,49 & 18 & 0,17 \\
\hline ATM & 482 & 6,29 & 394 & 3,80 \\
\hline BORSA- YATIRIM & 23 & 0,30 & 24 & 0,23 \\
\hline KİRALIK KASA & 14 & 0,18 & 4 & 0,04 \\
\hline ORTAK ATM & 301 & 3,93 & 42 & 0,41 \\
\hline DİĞER & 205 & 2,67 & 473 & 4,56 \\
\hline Müşteri Temsilcisi & 647 & 8,41 & 1316 & 12,70 \\
\hline ÇAĞRI MERKEZI & 159 & 2,09 & 498 & 4,80 \\
\hline ŞUBE PERSONELİ & 488 & 6,37 & 818 & 7,90 \\
\hline TOPLAM & 7652 & 100,00 & 10366 & 100,00 \\
\hline
\end{tabular}

Tablo 3'teki "bankanın sunmuş olduğu hizmetler ve ürünler" teması altında yer alan "kredi" ana kategorisine bakıldığında Ziraat Bankası'na iletilen şikâyet sayısının Garanti BBVA'nın şikâyet sayısının iki katından daha fazla olduğu görülmektedir. Toplam şikâyetlere olan oranı incelendiğinde Ziraat Bankası'nın bu ana kategori için \%20,94'lük bir oranı varken, Garanti Bankası \%7,17'lik bir orana sahiptir. Aradaki \%13,77'lik farkın büyük çoğunluğu Ziraat Bankası'nın kredi yapılandırma işlemleri ile ilgili hizmet aksaklıklarından kaynaklanmaktadır. Müşteriler düşen faiz oranlarını kredi ödemeleri konusunda avantaja çevirmek istemekte bankalar ise faiz gelirlerinde yaşanan kaybı yapılandırma masrafı ve komisyon adı altında telafi etmek istemektedir.

Online işlemler ana kategorisine bakıldığında Ziraat Bankası'nın internet bankacılı̆̆ı işlemlerinde Garanti BBVA'a göre yaklaşık iki kat daha fazla şikâyet aldığı görülmektedir. Analizler sonucunda şikâyetlerin büyük çoğunluğunun internet bankacılığında kullanılan şifrelerle ilgili olduğu tespit edilmiştir. Müşteriler aynı zamanda bloke olan şifrelerini yenilemek için çağrı merkezlerini aradıklarını ama sorunla ilgilenebilecek müşteri temsilcileri yerine sesli operatörlerle muhatap olduklarını dile getirmişlerdir. 


\section{Bozpolat - F. Çopur 13/3 (2021) 2056-2071}

Müşteri temsilcisi teması altında hem çağrı merkezi hem de şube personeli ana kategorilerinde Garanti BBVA'nın daha fazla şikâyet aldığı gözlenmiştir. Garanti Bankası'nın çağrı merkezi şikâyetleri; müşterisi olmayan kişileri çağrı merkezi aracılığıyla sürekli arayıp rahatsız etme, müşteri temsilcilerine ulaşamama ve ulaşıldığında ise üslupsuz konuşma şeklindedir. Şube personeli şikâyetleri ise genel olarak; şubede çalışan personel sayısının az olması ve müşteriye yaklaşımlarının kaba olması, personelin işlemleri yavaş yapması ve bu nedenle uzun süre sıra beklenmesi konularını kapsamaktadır. Ziraat Bankası yukarıda sıralanan Garanti Bankasının şikâyetlerine ek olarak çağrı merkezi kategorisinde telesekreteri aşıp müşteri temsilcisine bir türlü bağlanamama, müşteri temsilcisine bağlanılsa bile çözüm odaklı olmayıp şubeye yönlendirme; şube personeli kategorisinde ise güvenlik personellerinin kaba tavırları ve şubede yapılmak istenen işlemleri ATM'den yapmaya yönlendirme gibi şikâyetler yer almaktadır.

Her iki banka için ATM ana kategorisindeki şikâyetler incelendiğinde bankaların benzer konularda şikâyetler aldığı tespit edilmiştir. Bankalar ATM'ye para sıkışması, ATM'nin bozuk olması, kart yutması, paraya el koyması, işlem anında sorun yaşanıp fiziki olarak çekilmeyen paranın hesaptan çekilmiş gibi gösterilmesi, yatırılan paranın hesaba düşmemesi ve eksik para vermesi gibi konularda şikâyetler almıştır. Ortak ATM ana kategorisinde de Ziraat Bankası Garanti Bankası'na oranla daha fazla şikâyet almıştır. Şikâyetler, ATM kategorisindeki şikâyetlere benzer olmakla birlikte yaşanan problemler farklı ATM kartlarıyla yapılan işlemler sırasında gerçekleşmesi ile farklılaşmaktadır.

\section{SONUÇLAR ve TARTIŞMA}

Diğer tüm sektörlerde olduğu gibi bankacıllk sektöründe de başarının anahtarı müşteri memnuniyetidir. Memnun bir müşteri bankanın pazar payını attırırken mutsuz bir müşteri bankanın kazançlarının azalmasına neden olmaktadır (Yıldız Erduran ve Lorcu, 2020: 3857). Sektörde varlığını devam ettirmek isteyen bankalar, müşterilerinin memnuniyetsizlik yaşadığı hizmetlerle ilgili sorunlarını gerek işletme olarak birincil düzeyde gerekse çevrimiçi olarak ikincil düzeyde takip etmeli ve çözüm önerileri sunmalıdır. İkincil düzeyde veri sağlayan çevrimiçi şikâyet siteleri, olumsuz deneyim yaşayan müşterileri geri kazanma ve rekabet avantaj1 sağlama bakımından bir fırsattır.

Bankacılık sektörünün şikâyet sıralamasında dünyada 3. sırada olduğunu belirten Tax vd., (1998)'e göre şikâyetlerin etkin bir şekilde değerlendirilmesi ve çözülmesi; müşterinin tatmin ve dolayısıyla memnuniyet düzeyinin artmasına, memnuniyet ise banka sadakatinin oluşmasına ve hizmet satın alım miktarının artmasına ve tüm bu aşamalardan geçen müşterilerin başka müşterilere WOM aracıllı̆̆ıla önerilerde bulunmasına neden olmaktadır. Şikâyetleri çözmenin sağladığı bu faydalar e-şikâyetlerin derinlemesine incelenmesini gerekli kılmaktadır. Bu bağlamda finansal hizmet sağlayıcılarına çevrimiçi olarak iletilen şikâyetleri daha anlaşılır kılmak için içerik analizi yapılmış ve şikâyetler 2 tema, 12 ana kategori ve 15 alt kategori altında sınıflandırılmıştır. Eser vd., (2016) çalışmalarında şikâyetleri; kural, operasyon, çağrı merkezi, personel-şube, teknoloji ve diğer olmak üzere 6 ana kategoride sinıflandırmıştır. Şikâyetlerin banka bağlamında nicel verilere dönüştürüldüğü çalışmada şikâyet sayısı bakımından Garanti Bankası ilk sırada yer almıştır. Aynı durum kamu bankaları kategorisinde Ziraat Bankası için de geçerlidir. Bu ise mevcut çalışmanın sonuçlarını desteklemektedir. Eser ve arkadaşlarının çalışmasını bu çalışmadan ayıran temel farklılık, bankaların mevduat paylarını banka şikâyet sayıları ve yüzdeleri ile ilişkilendirmesidir. Şikâyet sayıları sektördeki tüm bankaları kapsamaktadır ama şikâyetlerin nedenlerine ilişkin bir değerlendirme yapılmamıştır. Mevcut çalışma ise kamu ve özel sermayeli banka özelinde şikâyetleri alt kategorilere ayırarak müşterilerin şikâyet nedenleri üzerine odaklanmakta ve bankalar arası karşılaştırma yaparak başarılı bir eCRM için yapılması gerekenler noktasında tavsiyelerde bulunmaktadır.

İlgili bankaların şikâyet tema ve kategorileri karşılaştırıldığında benzer konularda problemlerin olduğu görülmüştür. Analizler sonucu ortaya çıkan iki temadan ilki olan "bankanın sunmuş olduğu hizmetler ve ürünler" teması on ana kategori ile tüm şikâyetlerin dörtte üçünden fazlasını oluşturmaktadır. Bu e-şikâyetler kredi kartı ve hesap işlemleri, karta ve hesaba yansıtılan ücretlerin iadesi, kredi kullanımı ve yapılandırma işlemleri, online işlemler, para transfer işlemleri ve ücretleri, ATM, kiralık kasa, borsa-yatırım, altın işlemleri olmak üzere genel olarak finansal hizmet sağlayıcılarının hizmetlerinden yararlanırken yaşanan aksaklıklar ile ilgilidir. Sonuçlar, banka müşterilerinin hizmet alım sürecindeki kart ve hesap işlemleri, müşteri temsilciliği, aidatlar ile ilgili yaşanan problemlerden memnun olmadıkları yönündeki önceki çalışmaların bulgularını desteklemektedir (Yıldız Erduran ve Lorcu, 2020; Eser vd., 2016). Ayrıca Ziraat Bankası'nın “kart 


\section{Bozpolat - F. Çopur 13/3 (2021) 2056-2071}

teslimatı-kurye sorunu" alt kategorisinde en fazla şikâyet aldığı Eylül ayını takip eden aylarda şikâyet sayılarının azalması kart teslimatı konusundaki problemlerin çözülmeye çalışıldığının bir göstergesi olabilir. Öte yandan Ziraat Bankası'na "kart ve hesap işlemleri" ana kategorisinde "kart teslimatı ve kurye sorunu" alt kategorisi hariç diğer tüm kategorilerde altı aylık dönemde benzer sayıda şikâyette bulunulmuştur. Bu durum şikâyetlere etkili çözümler getirilmediğinin, bir önceki aylarda yaşanan şikâyetlerin sonraki aylarda da devam ettiğinin bir sonucudur. Uzun dönemde müşteri memnuniyeti ile karlılı̆̆1 benimseyen bankalar, şikâyet konusu hizmet aksaklıklarını giderici faaliyetlerde bulunmalıdır.

Şikâyetlerin ikinci teması olan "müşteri temsilcisi" teması, banka müşterilerinin çağrı merkezi ve şube personeli ile ilgili yaşadığı sorunları içermektedir. Çağrı merkezi personelinin empati yapmayıp sorunun çözümü için müşteriyi şubeye yönlendirmesi ve etkili iletişim konusunda yetersiz olması, şube personelinin işlemleri yavaş yapması, güvenlik personellerinin kaba ve uygunsuz tavırları bu temanın ana şikâyet konularıdır. Bu şikâyet konularının, personelin kaba ve özensiz tavırlarını içeren ulaşım ve konaklama sektöründe e-şikâyetleri inceleyen çalışmalardaki konularla benzerlik gösterdiği tespit edilmiştir (Harrison ve Walker 2001; Lee ve Hu, 2004; Berezina vd., 2016; Dinçer ve Alrawadieh, 2017: 794; Rosenmayer vd., 2018).

E-şikâyet konuları bankalar özelinde karşılaştırıldığında Garanti BBVA Ziraat Bankası'na oranla kredi kartı ve hesap işlemleri ile aidatlar kapsamında \%19,02 oranında daha fazla şikâyet almıştır. Bu oransal fazlalık Garanti BBVA'nın Ziraat Bankasına kıyasla kredi kartı çeşitliliğinin ve kullanım oranının daha fazla olması ile açıklanabilir. Diğer bir ana şikâyet kategorisi olan "kredi" kategorisinde ise; kredi yapılandırma işlemlerinde Garanti BBVA'ya oranla Ziraat Bankası'na daha fazla şikâyet iletilmiştir. Tüketicilerin faiz oranları ve yapılandırma süreçleri konusunda bilinçlenmesi ile birlikte müşteri ve banka arasında çıkar çatışmaları yaşanmakta bu ise müşteri şikâyetlerini beraberinde getirmektedir. Garanti BBVA yöneticileriyle yapılan görüşmelerde kredi yapılandırma işlemlerinde bankanın yapılandırma onay mercilerinin hızlı geri dönüş yapmasının şikâyet oranının az çıkmasına bir neden olarak gösterilebileceği söylenmiştir. Ziraat Bankası'nın ise en fazla şikâyet aldığı ağustos ayını takip eden aylarda kredi yapılandırma alt kategorisindeki şikâyetlerinin azaldığı görülmektedir. Bu durum ise yapılandırmada kullanılabilecek faiz düşüşlerinin geçici olması ile açıklanabilir. Müşteri temsilcisi teması altında yer alan personel şikâyetleri kategorisinde de Garanti BBVA, Ziraat Bankası'nın şikâyet sayısından iki kat fazla şikâyet almıştır. Bu ise kamu ve özel sektör çalışanlarının dışsal motivasyon seviyelerindeki farklılıklarla ilişkilendirilebilir (Buelens ve Broeck, 2007).

Müşterilerin şikâyet ettiği konular banka yönetiminin sorumluluğundadır ve bu konuda müşteriler şikâyetlerine çözüm sunulmasını beklemektedir. Ancak gerek şikâyet konularının müşterilerin kişisel hesap bilgilerini içererek cevaplanmasından gerekse çözüm önerilerinin metinsel ifade edilememesinden çevrimiçi geribildirimler yetersiz kalmaktadır. Bankalara iletilen toplam 18.018 şikâyetin sadece 1.484 'ü çözülmüştür. $\mathrm{Bu}$ ise şikâyetlerin \%8,24'üne karş1lık gelmektedir. Şikâyetlerin hepsinin otomatik sistem mesajı olarak cevaplanması ise ilginç bir sonuçtur. Garanti BBVA e-şikâyetlerinin \%100'ünü otomatik sistem mesajı ile cevaplarken Ziraat Bankası otomatik sistem mesajı ile cevaplanmasına rağmen şikâyetlere cevap verme oranı \%78'dir. Geribildirim noktasında bankanın e-şikayet yönetimini etkili bir şekilde yaptığını söylemek zordur. Çözümlerin büyük çoğunluğunun otomatik sistem mesajı şeklinde olması e-CRM'de başlangıç aşamasında olduğunun bir göstergesi olabilir. Bu bağlamda bankalara iletilen her 100 şikâyetten sadece 8'inin çözümlendiğini söylemek mümkündür. Bu sonuç Lee ve Hu (2004)'nun otel işletmelerinin her 100 şikâyetten 14'ünün cevaplandığını ifade ettikleri çalışmaları ile karşılaştırıldığında bankacılık sektöründeki işletmelerin e-şikâyetleri daha az dikkate aldığının bir göstergesidir.

Lee vd., (2003: 424) çalışmalarında, müşterilerin şikâyet etme oranının \%5 azaltılması durumunda hizmet endüstrilerinde kârın \%25 ila \%80 aralığında artacağını ifade etmişlerdir. Karlılığını artırmak isteyen bankalar ise e-şikâyetlere mümkün olduğunca kişiselleştirilmiş mesajlarla geribildirimde bulunmalıdır. Geçmişte yapılan çalışmalar, etkin şikâyet yönetiminin/geribildirmlerin yarattığı memnuniyetin, mevcut ve potansiyel müşterilerle uzun dönemli güçlü ilişkilerin kurulmasında ve sadakat yaratarak karlılı̆̆ın oluşmasında etkili olduğunu göstermiştir (Homburg ve Fürst, 2005; Rothenberger vd., 2008). Müşteri ilişkileri yönetimi kapsamında değerlendirilen bu bulgunun WOM'a pozitif katkısı, uzun dönemde marka imajının güçlenmesini sağlamaktadır (Clark vd.,1992). 


\section{Bozpolat - F. Çopur 13/3 (2021) 2056-2071}

\subsection{Sınırlamalar ve İleriki Araştırmalara Öneriler}

Araştırmada analiz edilen e-şikâyetler, sikayetvar.com sitesi ile sınırlıdır. Banka anahtar kelimesiyle yapılan taramada siteye 281.396 adet bankacılık işlemleriyle ilgili şikâyet iletildiği tespit edilmiştir. Şikâyet sayısının fazlalığından dolayı araştırma, e-şikâyet sayısı en yüksek iki banka (kamu ve özel sermayeli banka kategorileri özelinde) ve Temmuz 2019- Aralık 2019 tarihlerini kapsayan 6 aylık bir zaman dilimi ile sınırlandırılmıştır. Bu bağlamda daha fazla banka ve daha uzun tarih aralığı belirlenerek farklı bulgular elde edilebilir. Sektöre ilişkin tüm şikâyetleri incelemenin zor olduğu gerçeğinden yola çıkarak çalışmadan elde edilen sonuçların eCRM açısından faydalı bilgiler sunduğunu söylemek mümkündür. Ayrıca araştırmada değerlendirilen şikâyetlerin doğru ve tarafsız bir şekilde paylaşıldığı varsayılmıştır.

Bu araştırmada biri kamu diğeri özel sermayeli banka olmak üzere iki bankaya ilişkin e- şikâyetler analiz edilerek bankacılık sektörü için genelleştirilebilecek bulgular ortaya konulmuştur. Araştırma bulgularından yola çıkarak bankaların e-şikâyetlerini denetim altında tutabilmelerine olanak sağlayan bilgi teknolojilerini sistemlerine entegre etmeleri eşzamanlı e-CRM yapmalarını kolaylaştıracaktır. İnternet ve bilgi teknolojilerindeki gelişmeler e-şikâyetlerin anlık olarak dikkate alınıp çözüm sunulmasını zorunlu kılmaktadır. Bu nedenle finansal hizmet sağlayıcıları hizmet aksaklıkları sonucu olumsuz deneyim yaşayan müşterilerini geri kazanmak için teknolojik alt yapı, veri tabanı ve yazılımlarla desteklenmiş e-şikâyet yönetim sistemi kurmalıdır. Söz konusu sistem alt yapısını kurma bakımından mali yetersizlik yaşayan bankalar, sürekli olarak şikâyetleri izleyecek ve üst yönetime rapor sunacak dijital pazarlama uzmanlarını ya da veri analistlerini istihdam edebilirler.

İleriki araştırmalar banka geribildirimlerinin etkinliğinin e-NWOM ve E-PWOM üzerindeki etkisine odaklanabilir. Ayrıca e-şikâyetlere verilen otomatik sistem mesajı yanıtlarının müşteri memnuniyeti, müşteri değeri ve yeniden satın alma niyetine olan etkisi analiz edilerek e-şikâyet davranışını netleştirecek araştırmalar yapılabilir.

\section{KAYNAKÇA}

Anderson, E. W. (1998). Customer satisfaction and word of mouth. Journal of Service Research, 1(1), 5-17.

Arndt, J. (1967). Role of product-related conversations in the diffusion of a new product. Journal of Marketing Research, 4(3), 291-295.

Barlow, J., \& Møller, C. (2008). A complaint is a gift: recovering customer loyalty when things go wrong. San Francisci, Berrett-Koehler Publishers.

Berezina, K., Bilgihan, A., Cobanoglu, C., \& Okumus, F. (2016). Understanding satisfied and dissatisfied hotel customers: text mining of online hotel reviews. Journal of Hospitality Marketing \& Management, 25(1), 124.

Blodgett, J. G., Granbois, D. H., \& Walters, R. G. (1993). The effects of perceived justice on complainants' negative word-of-mouth behavior and repatronage intentions. Journal of Retailing, 69(4), 399-428.

Buelens, M., \& Van den Broeck, H. (2007). An analysis of differences in work motivation between public and private sector organizations. Public Administration Review, 67(1), 65-74.

Cambra-Fierro, J., Melero, I., \& Sese, F. J. (2015). Managing complaints to improve customer profitability. Journal of Retailing, 91(1), 109-124.

Chang, Y. W., \& Chang, Y. H. (2010). Does service recovery affect satisfaction and customer loyalty? An empirical study of airline services. Journal of Air Transport Management, 16(6), 340-342.

Chebat, J., \& Slusarczyk, W. (2005). How emotions mediate the effects of perceived justice on loyalty in service recovery situations: an empirical study. Journal of Business Research, 58, 664-673.

Cho, Y., Im, I., Hiltz, R., \& Fjermestad, J. (2002). An analysis of online customer complaints: implications for web complaint management. In Proceedings of the 35th Annual Hawaii International Conference on System Sciences, Big Island, HI, USA, 2308-23. 


\section{Bozpolat - F. Çopur 13/3 (2021) 2056-2071}

Clark, G. L., Kaminski, P. F., \& Rink, D. R. (1992). Consumer complaints: Advice on how companies should respond based on an empirical study. Journal of Consumer Marketing. 9(3), 5-13.

Conlon, D. E., \& Murray, N. M. (1996). Customer perceptions of corporate responses to product complaints: The role of explanations. Academy of Management Journal, 39(4), 1040-1056.

Dinçer, M. Z., \& Alrawadieh, Z. (2017). Negative word of mouse in the hotel industry: A content analysis of online reviews on luxury hotels in Jordan. Journal of Hospitality Marketing $\mathcal{E}$ Management, 26(8), 785-804.

Downe B, Wamboldt RN (2009). Content analysis: Method, applications, and issues, Health Care for Women International, 13(3), 313-321.

Dülek, B. (2019). Tüketicilerin marka memnuniyeti ile olumsuz ağızdan ağıza iletişim ve online şikâyet davranışları arasındaki ilişkinin analizi. Sosyal Bilimler Akademi Dergisi, 2(Özel sayı), 23-36.

Fisk, T. A., Brown, C. J., Cannizzaro, K., \& Naftal, B. (1990). Creating patient satisfaction and loyalty. Journal of Health Care Marketing, 10(2), 5-15.

Gelbrich, K. (2010). Anger, frustration, and helplessness after service failure: coping strategies and effective informational support. Journal of the Academy of Marketing Science, 38(5), 567-585.

Gelbrich, K., \& Roschk, H. (2011). A meta-analysis of organizational complaint handling and customer responses. Journal of Service Research, 14(1), 24-43.

Goldenberg, J., Libai, B., Moldovan, S., \& Muller, E. (2007). The NPV of bad news. International Journal of Research in Marketing, 24(3), 186-200.

Goodman, J. (1999). Basic facts on customer complaint behavior and the impact of service on the bottom line. Competitive Advantage, 9(1), 1-5.

Halstead, D., Droge, C. \& Cooper, M.B. (1993). Product warranties and post-purchase service: a model of consumer satisfaction with complaint resolution. Journal of Services Marketing, 7(1), 33-40.

Han, H.J., Mankad, S., Gavirneni, N. \& Verma, R. (2016). What guests really think of your hotel: text analytics of online customer reviews. Cornell Hospitality Report, 16(2), 3-17.

Harrison-Walker, L. J. (2001). E-complaining: a content analysis of an internet complaint forum. Journal of Services Marketing, 15(5), 397-412.

Hart, W.L., Heskett, J.L. \& Sasser, W.E. Jr (1990). The profitable art of service recovery. Harvard Business Review, 1(1), 148-156.

Hawkins, D. I., \& Mothersbaugh, D. L. (2010). Consumer behavior: Building marketing strategy. Boston: McGrawHill Irwin.

Homburg, C., \& Fürst, A. (2005). How organizational complaint handling drives customer loyalty: an analysis of the mechanistic and the organic approach. Journal of Marketing, 69(3), 95-114.

İlban, M. O., Demir, M. Ö., Arsezen-Otamış, P., \& Gündoğdu, M. (2021). Tatile çıkmadan önceki bilgi arayışlarının ağızdan ağıza iletişim ve davranışsal niyet üzerindeki etkisi: Edremit körfezi örneği. Seyahat ve Otel İşletmeciliğ̀i Dergisi, 18(1), 166-184.

Jeong, E., \& Jang, S. S. (2011). Restaurant experiences triggering positive electronic word-of-mouth (eWOM) motivations. International Journal of Hospitality Management, 30(2), 356-366.

Johnston, R. (2001). Linking complaint management to profit. International Journal of Service Industry Management, 12(1), 60-69.

Jung, N. Y., \& Seock, Y. K. (2017). Effect of service recovery on customers' perceived justice, satisfaction, and word-of-mouth intentions on online shopping websites.Journal of Retailing and Consumer Services, 37(July), 23-30. 


\section{Bozpolat - F. Çopur 13/3 (2021) 2056-2071}

Karakostas, B., Kardaras, D., \& Papathanassiou, E. (2005). The state of CRM adoption by the financial services in the UK: an empirical investigation. Information \& Management, 42(6), 853-863.

Kassarjian H. H. (1977). Content Analysis in Consumer Research. Journal of Consumer Research, 4(1), 8-18.

Kılıç S (2015). Kappa testi. Journal Of Mood Disorders, 5(3), 142-144.

Kim, T. T., Kim, W. G., \& Kim, H. B. (2009). The effects of perceived justice on recovery satisfaction, trust, word-of-mouth, and revisit intention in upscale hotels. Tourism management, 30(1), 51-62.

Lau, G. T., \& Ng, S. (2001). Individual and situational factors influencing negative word-of-mouth behaviour. Canadian Journal of Administrative Sciences, 18(3), 163-178.

Lee, C. C. \& Hu, C. (2004). Analyzing hotel customers' e-complaints from an internet complaint forum. Journal of Travel \& Tourism Marketing, 17(2-3), 167-181.

Lee, S., Barker, S., \& Kandampully, J. (2003). Technology, service quality and customer loyalty in hotels: Australian managerial perspectives. Managing Service Quality, 13(5), 423-432.

Mattila, A. S., \& Mount, D. J. (2003). The impact of selected customer characteristics and response time on ecomplaint satisfaction and return intent. International Journal of Hospitality Management, 22(2), 135-145.

Maurer, C., \& Schaich, S. (2011). Online customer reviews used as complaint management tool. Information and Communication Technologies in Tourism, 499-511.

McCollough, M. A. (2000). The effect of perceived justice and attributions regarding service failure and recovery on post-recovery customer satisfaction and service quality attitudes. Journal of Hospitality \& Tourism Research, 24(4), 423-447.

Mitchell, V. W. (1993). Handling consumer complaint information: How and why? Management Decision, 31(3), 21-28.

Nair, K. S., \& Radhakrishnan, L. C. (2019). Role of eWOM in customer buying decision-making process: A conceptual study. International Journal on Emerging Technologies, 10(4), 71-75.

Park, C., \& Lee, T. M. (2009). Information direction, website reputation and eWOM effect: a moderating role of product type. Journal of Business Research, 62(1), 61-67.

Pourmand, J. \& Lari, M. A. (2016). The study of relationship management with electronic customer on the quality of customer relationship in Mellat Bank. International Journal of Education and Management Studies, 6(3), 300-304.

Ravi, K., Ravi, V., \& Prasad, P. S. R. K. (2017). Fuzzy formal concept analysis based opinion mining for CRM in financial services. Applied Soft Computing, 60, 786-807.

Rosenmayer, A., McQuilken, L., Robertson, N. \&Ogden, S. (2018). Omni-channel service failures and recoveries: refined typologies using Facebook complaints. Journal of Services Marketing, 32(3), 269-285.

Rothenberger, S., Grewal, D., \& Iyer, G. R. (2008). Understanding the role of complaint handling on consumer loyalty in service relationships. Journal of Relationship Marketing, 7(4), 359-376.

Sarı, F. Ö., \& Onat, F. (2013). E-complaining: analysis of lodging customers'e-complaints from a turk-ish internet website. In Proceedings of the 2013 International Conference on Information, Business and Education Technology (ICIBET). Atlantis Press, 843-847.

Singh, J. (1988). Consumer complaint intentions and behavior: definitional and taxonomical issues. Journal of Marketing, 52(1), 93-107.

Stauss, B., \& Seidel, W., (2004). Complaint management: the heart of CRM. Mason: Thompson/South-Western.

Sujitha, K.A. \& Johnson, B. (2017). Electronic customer relationship management (e-CRM) techniques for effective banking. Finance India, 31(1), 223-232. 


\section{Bozpolat - F. Çopur 13/3 (2021) 2056-2071}

Sundaram D.S., Mitra K. , \& Webster C. (1998). Word-of-mouth communications: a motivational analysis. Association for Consumer Research, 25, 527-531.

Tax, S. S., Brown, S. W., \& Chandrashekaran, M. (1998). Customer evaluations of service complaint experiences: implications for relationship marketing. Journal of Marketing, 62(2), 60-76.

Taylor, S.A. \& Baker, T.L. (1994). An assessment of the relationship between service quality and customer satisfaction in the formation of consumers' purchase intentions. Journal of Retailing, 70(2), 163-168.

Tyrrell, B. \& Woods, R. (2004). E-complaint: lessons to be learned from the service recovery literatüre. Journal of Travel \& Tourism Marketing, 17 (2-3), 183-190.

Vaismoradi M., Jones J., Turunen H., \& Snelgruve S. (2016). Theme development in qualitative content analysis and thematic analysis. Journal of Nursing Education and Practice, 6(5), 100-110.

Wang, J., Wang, X., \& Li, Y. (2019). A discrete electronic word-of-mouth propagation model and its application in online social networks. Physica A: Statistical Mechanics and Its Applications, 527(121172), 1-11.

Weiner, B. (2000). Attributional thoughts about consumer behavior. Journal of Consumer Research, 27, 382-387.

Wetzer, I. M., Zeelenberg, M. \& Peiters, R. (2007). Never eat at that restaurant, I did! Exploring why people engage in negative word of mouth communication. Psychology and Marketing, 24(8), 661-680.

Wu, R., \& Wang, C. L. (2017). The asymmetric impact of other-blame regret versus self-blame regret on negative word of mouth. European Journal of Marketing. 51(11-12), 1799-1816.

Yang, J., \& Mai, E. S. (2010). Experiential goods with network externalities effects: An empirical study of online rating system. Journal of Business Research, 63(9-10), 1050-1057.

Yang, Y., Park, S., \& Hu, X. (2018). Electronic word of mouth and hotel performance: A meta-analysis. Tourism Management, 67, 248-260.

Yıldırım, A. \& Şimşek, H. (2018). Sosyal Bilimlerde Nitel Araştırma Yöntemleri. Seçkin Yayınları, 11.Baskı, Ankara.

Ylldiz Erduran, G., \& Lorcu, F. (2020). The investigation of online customer complaints in the banking sector by text mining, BMIJ, 8(5), 3835-3866.

Zaby, C., \& Wilde, K. D. (2018). Intelligent business processes in CRM. Business \& Information Systems Engineering, 60(4), 289-304. 